\title{
Determining the Criteria Identifying Teacher Performance Through Multiple Indicators
}

\author{
Sanem Dilbaz Sayin \\ PhD Candidate in the Field of Education \\ Hasan Arslan \\ Head of Department of Educational Sciences, \\ Canakkale Onsekiz Mart University/Turkey
}

doi: 10.19044/esj.2017.v13n16p19 URL:http://dx.doi.org/10.19044/esj.2017.v13n16p19

\begin{abstract}
This study focused on determining the criteria for the assessment of teachers' performance. It aimed to determine 'Teachers' Performance Assessment Scale' through the opinions of teachers, administrators, and students. Semi-structured interviews were conducted to gather the opinions of the participants. Four education-specialists took part in the interviews and analysis of the data. The data were analyzed by means of factor analysis and varimax method was used to reduce the items and group the related ones. According to the results, 'Teacher Performance Assessment Scale' included 39-item and 6 sub-dimensions. Besides, self-evaluation and long term observation of multiple indicators were found to be the most appropriate ways to evaluate teachers' performance.
\end{abstract}

Keywords: Performance Criteria, Teachers' Performance, Assessing Teachers' Performance

\section{Introduction}

Assessment processes are used to monitor the effectiveness of teachers, who are important directors of the educational process. In this process, as well as assessing the performance of teachers, schools should also be included in the performance evaluation process by making performance definitions owing to the fact that the high performance of a teacher or school administrator in a school alone is not enough to achieve the expected quality of education.

The teachers develop negative attitudes toward their performance evaluation process and criteria due to several factors, such as determination of the criteria by the ministry of education directly and inability to represent all teachers' profiles in the workshops. The performance priorities of 
teachers working in different residential units, environments with different socio-economic structures, and school climate vary according to working conditions. The centrally determined criteria may cause difficulties for teachers working in village schools with hardware deficiencies. While the performance evaluation criteria are being developed, teachers expect establishment of general criteria by referring to the opinions of teachers who work in different schools.

In the present study, it was aimed to determine the criteria to be used in measuring the professional performance of the teachers working at state schools through the views of teachers, administrators, and students. The evaluation criteria determined as a result of interviews with are expected to meet the demands of teachers.

\section{I.}

Education is not a profession that everyone can practice, it is rather a special profession that can only be practiced by the specially trained teachers. Currently, schools are taking over the roles and the responsibilities of families. Thus, it is expected from schools to create a secure and affectionate learning environment where each student expresses himself freely, develops himself, and learns new things. Moreover, in this learning environment teachers are expected to be the role model for their students with their knowledge, capabilities, and virtues (Darling-Hammond, 2006).

Teachers are the role models for the young students so that they can develop positive behavior and understanding toward themselves and the society. Teachers are also expected to manage the time effectively. The lessons should be meticulously designed in line with the learning outcomes (National Union of Teachers, 2011). In this sense, teaching is a profession that could be performed by the individuals who know and love this profession. Teaching also is a profession that requires special training and unique dedication (Darling-Hammond, 2006)

Teacher candidates are one of the most important factors of the education system. When the teacher candidates are trained in a qualified way, they can be the qualified teachers of the future. It is not possible for the teachers who do not know or interpret their students precisely to manage the teaching process effectively (Beytekin, Kadı \& Toprakçı, 2015). “Teaching is a special and significant profession and a blessed occupation that has to be put into practice by well-trained experts" (Özcan, 2011, p. 5). The qualified education is only conveyed to the youth through the qualified teachers.

The new focus of the education in the current era is to be able to educate youth with the capability of reaching the exact information through a competent, virtuous, and critical way of thinking (Özcan, 2011). Individuals’ 
life and their expectations from the life are affected by economic, social, and cultural changes. These expectations make the changes for the education system necessary. Teachers, the main practitioners of the education system, need to adapt the changes and have the qualifications that the current educational process demands. Thus, the answer of the question 'What are the criteria that teachers should have?' should be found out. By this way, the competencies that the teachers should have should be updated to keep up with the time (Çetin, Sarıdaş \& Araç, 2015).

According to the definition of The Department of Inspection Board (2006), the performance assessment is a way of giving feedback to the employees by evaluating their performance through the predetermined criteria. The main purpose of teachers' performance assessment process is to evaluate teachers' practice in an objective way by means of the feedback. (Ministry of National Education, 2006). The fact that teachers receive feedback about their teaching performance in a longer period compared to other professions reveals the need for a different method of evaluation (Peterson, 1995).

Considering the performance assessment system in educational institutions, the assessment is the determination of how the teachers' and administrators' outputs are effective in accordance with the pre-determined capabilities. Using the performance assessment process in educational institutions effectively reveals that the assessment and standardization are significant also in education system which is consistent with the changes taking place (Buyruk, 2014). The evaluation of the teachers' performance level is considered as the fundamental factor for teachers' professional development. This process involves some procedures, such as assessing teachers' performance and determining the appropriate methods to reach the desired performance level (Newstrom,1993).

Erdoğan (1991) defines the performance as the workers' performing the task, which is suitable for the workers' qualities and abilities, within acceptable limits. Besides, the performance is defined as the qualitative and quantitative measure of how far the organization achieves its goals (Özkanl,, 1995). The assessment process is the objective evaluation of the employees' effort by means of the pre-determined criteria.

\section{Literature Review}

Various assessment processes have been used to evaluate the performance of teachers. However, the literature reveals that the 360 Degree Performance Assessment System is the most preferred one as for meeting the needs of the era by giving feedback to teachers and giving them the choice of noticing different perspectives. Altan (2005), in his study, tried to figure out an evaluation model by defining the state administrators' perspective for the 
evaluation system. The results of the study showed that the state administrators found the present evaluation system inefficient. In addition, the results indicated that the 360 Degree Performance Assessment System was needed to use in the process effectively. To accomplish the procedure, the performance of the teachers should be formed with the views of students, students' parents, colleagues of teachers, and administrators (EARGED, 2006).

When the literature is reviewed about the performance assessment of teachers, it is mostly seen that "360 Degree Performance Assessment System" is the most popularly used one. In order to assess the performance of teachers, it is suggested that the opinions of administrators, students, students' parents, colleagues as well as the self-evaluations should be taken into consideration. Performance results are seen as more transparent and legal through the 360 Degree Performance Assessment System. This assessment system has an innovative structure and it provides a better feedback for the teachers (Şenol, 2003).

Moreover, the use of 360 Degree Performance Assessment System enables teachers to see their occupational performance objectively. As the teachers work alone in the classroom, getting the objective evaluations from multiple indicators facilitates them to differentiate their classroom environment and also be aware of the innovations. With this aim, Ministry of Education prefers to use 360 Degree Performance Assessment System instead of using the time-honored practice of the centralized management system. Teachers' roles in the current era have changed. They are not disseminators of knowledge anymore, rather they are facilitators, guides, and assistants in their students' learning (Schreyer Institute for Teaching Excellence, 2007).

The following research question will guide the present study:

What are the criteria that should be used in the teacher performance assessment process according to the opinions of teachers, administrators, and students?

\section{Methodology}

The present study applied a qualitative research method. Using this method in researches enables researchers to define a pattern or systemic issue or identification of a theory. The researchers using qualitative method gather data in different ways, such as participant observation, non-participant observation, field notes, structured interviews, semi-structured interviews, or unstructured interviews and analysis of materials (Creswell, 2013). 


\section{Participants and Setting}

The target population of the present study is all the students, teachers, and administrators working at any kind of state schools in Çanakkale. In accordance with the data gathered from Çanakkale Provincial Directorate of National Education, there are 5.495 teachers, 400 administrators, and 72.301 students enrolled in 398 state schools (Çanakkale MEM, 2016).

The research has been carried out by using the qualitative method. The representative sample of the qualitative method is 126 teachers, 17 administrators, and 378 students in the study area. Firstly, structured interviews were conducted with the teachers and administrators to find out the professional and personal characteristics of a successful teacher. Secondly, the students studying with these teachers and administrators were also required to provide these characteristics as well. Thirdly, the structured interview was carried out with four academicians who are educational specialists. The academicians' responses and the literature review were used to identify how useful the answers of teachers, administrators, and students to be used in 'Teachers' Performance Assessment Scale'. On the other hand, 390 teachers and administrators working at state primary, secondary, and high schools in Çanakkale, participated in the quantitative method of the study. The participants of the study were chosen randomly from all the state schools in the study area.

\section{Research Instrument}

'Teachers' Performance Assessment Scale', was developed with the opinions of the students, teachers, and administrators. The instrument was developed by identifying the skills students wanted to see in their teachers or teachers' and administrators' privileges about their colleagues. To construct the items coming up with the interviews, the teachers' competencies in teaching process identified in literature and academicians' opinions who are experts in the field of education were used. After determining the items of 'Teachers' Performance Assessment Scale', the teachers and administrators were asked to rate their performance on 5-point Likert type scale of strongly agree (5), mostly agree (4), partially agree (3), mostly disagree (2), and strongly disagree (1).

The developed instrument was validated by four education specialists working in different educational departments at different universities. The research question as well as the items gathered from the interviews conducted with the students, teachers, and administrators were given to them for scrutiny. They were asked to analyze the instrument in terms of level of language of expression, ambiguity, duplication of statement, relevance of items to research purpose and research questions. The comments and 
suggestions were used in composing the final copy of the data collection instrument as 'Teachers’ Performance Assessment Scale’.

The reliability of the instrument was determined using Cronbach's Coefficient alpha which was found to be 0.97. This finding showed that the reliability of the questionnaire was high.

\section{Data Collection Procedure}

The data collection tool was applied in six primary and secondary state schools which were chosen randomly in the study area. The schools' different characteristics are listed as below;

- Two primary and secondary state school located in villages,

- One primary and one secondary state school located in low socio-economic districts,

- Two primary state schools located in high socio-economic districts.

Working with the schools, which have different characteristics and which are located in different districts of Çanakkale, enabled us to analyze the various perspectives of the teachers, administrators, and students about the teachers' performance assessment process. For the qualitative part of the research, interviews were carried out by 126 teachers, 17 administrators, and 378 students in Çanakkale. Throughout the interviews, the responses to the question 'What are the professional and personal characteristics of a successful teacher?' were found out. The answers to this question were shared with four different academicians who are the experts in the field of education. With the use of varimax rotation technique, a-39-item 'Teacher Performance Assessment Scale' was formed.

For the second part of the research, the teachers and administrators evaluated their performance according to this scale. The 'Teacher Performance Assessment Scale' was responded by 390 teachers and administrators working at primary and secondary state schools in Çanakkale via the online link of the questionnaire. Using the online link of the questionnaire enabled a high rate of return of the questionnaire.

\section{Analysis}

The responses of the participants in the interviews were analyzed with content analysis. The responses of the participants are defined systematically with the help of content analysis. The data gathered from the participants were categorized. Following this step, the similar ones were gathered together and the items were interpreted in terms of sub-dimensions. For the content analysis, the records of the interviews with participants were analyzed and checked. While interviewing with the education specialists, the same procedure was followed. The similarities in the expressions were 
represented as in groups. In accordance with the feedback of education specialists, some of the items were taken out and some of the definitions were changed. With these changes, 59-item 'Teachers' Performance Assessment Scale’ was ready for the initial pilot practice. The validity of the instrument was determined by factor analysis. Through the factor analysis, the number of the items was reduced. The items related to each other were grouped. In addition, independent statistically meaningful items were created. The aim of the factor analysis was to reduce the number of the items and categorize them by defining the relationship between the items (Kalayc1, 2010). In order to check whether the instrument was suitable for factor analysis, explotorary factor analysis was conducted. The calculated KMO value of the scale was 0.944 which meant that the instrument was exactly suitable for the factor analysis. To use the varimax method, it is required that each item needs to be at 0.45 value to be included in the scale. The items below 0.45 value were removed form the research instrument.

\section{Findings}

After performing the factor analysis, 15 items (2, 10, 21, 25, 30, 31, 37, 40, 41, 43, 44, 46, 49, 51, 52) were taken out of 'Teachers' Performance Assessment Scale'. After the use of the varimax method, it was concluded that 'Teachers' Performance Assessment Scale' included 39 items and 6 dimensions. The items and sub-dimensions are listed as below:

I. Professional development and Valuing Students: The first sub-dimension consists of two sub-sections

'a) Following professional Developments' and

'b) Valuing Students' with a total of 8-items.

\section{Ia) Following professional Developments, 3 items}

19. The teacher places emphasis on developments as a professional, participates in in-service trainings, works as a researcher, and follows the literature in his field.

45. The teacher is hardworking and eager to do scientific researches.

3. The teacher is open to learning and innovation. The teacher follows and implements the innovations not only in education but also in his field.

\section{Ib) Valuing Students, 5 items}

1. The teacher places particular importance on students in different levels and assesses the students' learning potentials.

6. The teacher is knowledgeable in his field and the teacher can transfer his knowledge to his students.

8. The teacher communicates with his students effectively and empathizes with his students and parents. 
24. The teacher attracts the students' attention by using the body language effectively.

32. The teacher realizes the shortcomings of the students through the evaluations and repetitions.

\section{Arranging the Learning Environment, 7 items}

50. The teacher makes changes in accordance with the students' interests and needs in the teaching and learning process.

38. The teacher takes into consideration both students' and the school environments' interests and needs while choosing homework and outof-classroom activities.

42. The teacher is honest and consistent in his behaviors.

29. The teacher is a good listener, the teacher listens to all of his students and pays attention to their ideas.

14. The teacher loves children and practices his profession willingly.

16. The teacher assesses the students' diversities in accordance with the multiple intelligences theory.

17. The teacher is open to criticism and development, the teacher can self-criticize.

\section{The Classroom Interaction, 9 items}

28. The teacher is disciplined in classroom management and in all the interactions with his students.

36. The teacher arranges the seating order to facilitate students' learning process and in accordance with students' features.

53. The teacher directs his students to use their in-class and out-ofclass time effectively.

23. The teacher is open to co-operation and willing to share.

33. The teacher uses the board in a well-organized and apprehensible way.

12. The teacher uses his experience effectively in the profession.

13. The teacher takes radical decisions about students' developments, the teacher is self-sacrificing and devoted to his job.

27. The teacher determines the boundaries of his relationship with his students, the teacher treats each student equally and gives equal opportunity to his students during the lesson.

34. The teacher takes decisions with his students and applies them.

IV. Contributing to Students' Development, 6 items

5. The teacher is ready for his courses with the needed documents.

7. The teacher is pedagogically sufficient and expert in his field.

11. The teacher is aware of his responsibilities for his courses.

15. The teacher knows his students personally and enriches his courses by taking into consideration his students' individual differences. The teacher is creative. 
20. The teacher creates a free learning environment and educates students who think and express themselves freely.

39. The teacher plans his activities and while implementing his activities, the teacher aims to take each of his student further than the current level of their knowledge.

\section{$V$. Being in interaction with the School Environment, 4 items}

47. While working for the development of the school, the teacher cooperates with his students, his colleagues, local authorities, professional organizations, and non-governmental organizations.

48. The teacher participates in the school's social, professional, and cultural activities and acts as a leader when it is needed.

35. The teacher organizes extracurricular activities with his students and spends time with them outside of class hours.

9. The teacher uses games and entertaining activities during the courses, enriches the lesson with various activities.

\section{Being the Role Model to His Students, 5 items}

4. The teacher is a role model to his students by reflecting the social values to them.

18. The teacher speaks his native language appropriately and becomes a model to his students with his elocution.

22. The teacher has a high ability of persuasion and expression.

26. The teacher plays an active role in the process of problem solving.

54. The teacher guides the parents in solving the problems students experience throughout their study period.

\section{Conclusion and Suggestions}

With this present research, it is concluded that teachers do not prefer the time-honored practices activated with limited-time and limitedbackground knowledge. Instead, teachers are in favor of evaluating their performance through multiple indicators with a long term observation. This finding lends support to Gözütok (2000) who found that the most suitable method for the teachers' performance assessment process was selfevaluation. As a conclusion, the results indicated that for the teachers who are aware of using the scientific research methods, ready for improving themselves, open to the innovations and also have high motivation, the most appropriate assessment process should include multiple indicators.

The findings showed that 'Teachers' Performance Assessment Scale' is combined of 6 sub-dimensions. 'Professional development and Valuing Students', '1a) Following professional Developments' , '1b) Valuing Students', 'II. Arranging the Learning Environment', 'III. The Classroom Interaction', 'IV. Contributing to Students' Development', 'V. Being in 
interaction With the School Environment', 'VI. Being the Role Model to His Students'.

Besides, Ministry of Education EARGED (1999) conducted a research to analyze what the qualifications of modern teachers should be. It was stated that giving importance to the improvement of students, classroom activities, skills at communication technologies, professional development, and social relationship were the significant sub-dimensions. It can be concluded that the dimensions of 'Teacher Performance Assessment Scale' are similar with the dimensions of the research carried by EARGED.

In the study conducted by EARGED (1999), the reason for having the skills of information communication technologies comes to the forefront. It might have come out with the decisions taken by the VI. Five-Year Development Plan (1989). It was decided to take necessary measures to expand the computer-assisted instruction in the VI. Five-Year Development Plan (Aksoy, 1989 cited in Çeliköz, 1997). The development of the societies and the efforts of the education system to keep pace with the era are highlighting different aspects of the teaching profession. In the research conducted in 1999, teachers' ability to use new methods and computers in their lessons effectively was stood out. For this reason, the 'Role Modeling' factor has come to the forefront in the ability of teachers to have the skills of ICT. With the development of technology, the convenience of accessing information has increased the importance of using the right information and accessing the information correctly. For this reason, teachers' role modeling is the foreground in this research. So teachers' responsibilities include helping students develop deeper knowledge in specific topics. They are considered as role models in their societies (Eacute \& Esteve, 2000).

Along with the development of technology, accessing the right information and using the information in an appropriate way became more important. As a result, in this research teachers' 'being the role model to his students' dimension comes into prominence. In the study conducted by Oğuz (2006), the criteria for the administrators' performance assessment process were examined through the perspectives of teachers, inspectors, and administrators. Teachers' mostly highlighted performance assessment criteria for administrators was healthy communication based on administrators' listening to both school staff and parents. On the other hand, administrators emphasized the importance of following the educational developments and the criteria related to administrative processes. In addition, inspectors focused on the criteria related to the schools' getting ready for education. In this sense, the performance assessment criteria found in this study differ from the results of the study carried out by Oğuz (2006).

The studies carried out by Education Ministry in 2006 created an insecure working environment among teachers and let teachers think that 
administrators were criticizing them rather than giving feedbacks. In addition, the results could not be put into practice and the research failed to create a performance assessment tool for the teachers working at state schools. For this reason, it is crucial to develop a teacher performance assessment scale and put it into practice (Bayram, 2006).

This study has some implications for the administrators of Education Ministry while renewing the currently used teachers' performance assessment scale by holding out interviews or conferences to gather the ideas of teachers and administrators. The results indicated that teachers were in favor of the use of long-term observation and self-evalution as a tool of performance assessment. Thus, the managements of schools may use the compentencies identified as needed by a high-performance-teacher and develop their schools' own assessment instrument. Currently, school administrators' roles are changing in accordance with the changes and innovations in the modern world. Their main responsibility in this changing nature is to manage and control these changes and benefit from them in their organizations (Beytekin \& Arslan, 2017).

As a final remark, the results of this study were limited to the opinions of the students, teachers, and administrators participated in the research. In addition, the data gathered through the participants were limited to the instrument formed by the researcher. Future researchers may employ 'Teachers' Performance Assessment Scale' with a larger sample in order to obtain more generalizable results.

\section{References:}

1. Altan, Y. (2005). Türk kamu personel yönetiminde performans değerlendirmesi sistemi ve çă̆daş bir model önerisi. Isparta, Süleyman Demirel Üniversitesi Sosyal Bilimler Enstitüsü.

2. Bayram, L. (2006). Geleneksel Performans Değerlendirme Yöntemlerine Yeni Bir Alternatif: 360 Derece Performans Değerlendirme. Sayıştay Dergisi, 62, 47-65.

3. Beytekin, O. F., Kadı, A. \& Toprakçı, E. (2015). Öğretmen Adaylarının Kontrol Odă̆ Inançları ve Eğitim Felsefeleri. Yükseköğretim Dergisi, 5 (1), 1-8.

4. Beytekin, O. F. \& Arslan H. (2017). Entrepreneurial Leadership Characteristic of Schools Administrators. Impact Educational, 1, 6369.

5. Buyruk, H. (2014). Öğretmen performansının göstergesi olarak merkezi sinavlar ve ĕ̆itimde performans dĕ̆erlendirme. Trakya, Trakya Üniversitesi Eğitim Fakültesi Dergisi, 4 (2), 28-42. 
6. Creswell, J. W. (2013). Qualitative Inquiry And Research Design: Choosing Among Five Approaches (3rd Ed.). Thousand Oaks, CA: Sage.

7. Çetin, M., Sarıdaş, G., Araç, İ. (2015). Ĕgitim Denetimi Uygulamalarl Kapsamında Öğretmenlere Göre Öğretmenlerin Performans Değerlendirmesine İlişkin Bir İnceleme. 7. İzmir, Uluslararası Eğitim Denetimi Kongresi.

8. Darling-Hammond, L. (2006). Constructing 21st-Century Teacher Education. Journal of Teacher Education, 57 (X), 1-15.

9. Eacute, J., \& Esteve, M. (2000). The Transformation of the Teachers' Role at the End of the Twentieth Century: New challenges for the future. Educational Review, 52 (2), 197-207.

10. EARGED (1999). Eğitim Teknolojisi Kılavuzu. Ankara: Milli Eğitim Bakanlığ 1 .

11. EARGED (2006). Okulda Performans Yönetimi Modeli. Ankara: Milli Eğitim Bakanlığı.

12. Erdoğan, İ. (1991). Isşletmelerde Personel Seçimi ve Başarı Değerlendirme Teknikleri. İstanbul: İ.Ü İşletme Fakültesi Yayınları.

13. Gözütok, D. (2000). Öğretmenliğimi Geliştiriyorum. Ankara: Siyasal Kitabevi.

14. Kalayc1, Ş. (2010). Spss Uygulamalı Çok Değişkenli İstatistik Teknikleri (5. Baskı). Ankara: Asil Yayın Dağıtım.

15. Minisitry of Education (2006). Öğretmenlik Mesleği Genel Yeterlikleri. Ankara.

16. National Union of Teachers. (2011). Teachers' Working Time and Duties. National Union of Tecaher's Guide Book, 23-24.

17. Newstrom, J. D. (1993) Appraising and Rewarding Performance, Organizational Behavior, Human Behavior At Work, Series In Management. 167-176, Arizona State University: Mc. Graw Hill, University of Minessota.

18. Oğuz, E. (2006). İlköğretim Okulu Yönetici Performansını İlişkin Görüssler ve Öneriler. Kuram ve Uygulamada Eğitim Yönetimi, 46, 227-258.

19. Özcan, M. (2011). Bilgi Çă̆ında Öğretmen Ĕ̆itimi, Nitelikleri ve Gücü Bir Reform Önerisi. Ankara, Türk Eğitim Derneği (Ted) İktisadi İşletmesi.

20. Özkanl1, Ö. (1995). Personel Politikalarının Belirlenmesinde Performans Değerlemenin Yeri ve Ülkemiz Büyük Sanayi Işsletmelerindeki Uygulama (Doktora Tezi), Ankara.

21. Peterson, K. D. (1995). Teacher evaluation: A comprehensive guide to new directions and practices. Thousand Oaks, CA: Corwin. 
22. Schreyer Institute for Teaching Excellence. (2007). Teacher as Facilitator. State College: Pennsylvania State University.

23. Şenol, G. (2003). İş Değerlemesinden Performans Değerlemesine Geçiş. Bursa ,Uludağ Üniversitesi, İIBF., İşletme Bölümü. 